\title{
GATA-Binding Factor 3 Staining Method
}

National Cancer Institute

\section{Source}

National Cancer Institute. GATA-Binding Factor 3 Staining Method. NCI Thesaurus. Code C122842.

An immunohistochemical technique used to detect the presence of GATA-binding factor 3 in a tissue sample. 